\title{
Market Economies of the Western Balkans Compared to the Central and Eastern European Model of Capitalism
}

\section{Beáta Farkas}

The Institute of Finance and International Economic Relations, University of Szeged, Hungary

bfarkas@eco.u-szeged.hu

\author{
CroEconsur \\ Vol. 19 \\ No. 1 \\ June 2017 \\ pp. 5-36
}

Received: April 19, 2016

Accepted: March 2, 2017

Research Article

doi:10.15179/ces.19.1.1

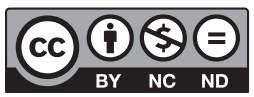

\section{Abstract}

Using the Central and Eastern European model of capitalism, this paper compares the market economies of the Western Balkan countries to the postsocialist European Union member states. It analyzes the main institutional areas of a socio-economic system such as product markets, innovation system, financial system, labor market and industrial relations, social protection and the educational system. The comparison of institutional systems does not provide an unambiguous answer to the question of whether the Western Balkan market economies fit into the model. There are many similarities between the institutional arrangements of the two regions, and the differences seem to be a consequence of delayed reforms rather than of an alternative model. However, the question 
of whether the current differences will be institutionalized or whether they will create a new normality - a new, distinct model of capitalism-remains open.

Keywords: Central and Eastern European model of capitalism, economic transformation, Western Balkans, institutional comparison

JEL classification: P16, P30, P52

\section{Introduction}

The communist system collapsed in the Western Balkan (WB) countries at the same time as in the Central and Eastern European (CEE) countries. However, the conflicts and wars which accompanied the dissolution of Yugoslavia impeded the economic transformation from a socialist self-management system to a market economy. The reforms of transition have been achieved over the past 15 years. In 2015 both the International Monetary Fund (IMF) and the Vienna Institute for International Economic Studies (wiiw) published comprehensive reports on the economic transition and current challenges of the WB countries (Murgasova et al., 2015; Gabrisch et al., 2015). The question arises regarding the similarities between institutional settings of this region and CEE countries' institutional arrangements. Relying on the results of an empirical investigation, I assume in this paper that a distinct model of CEE capitalism can be outlined in the European Union. First, I summarize the essential features of this model, then I compare the institutional areas of the socio-economic system in the CEE model to the institutions of the WB countries. It must be emphasized that it is a very preliminary analysis and the aim of this paper is to provide ideas for further research rather than to reach final conclusions. 


\section{The Model of Capitalism in Central and Eastern Europe}

Globalization and the fall of the Soviet Empire have made it timely to question whether countries are heading for a single model of capitalism as a result of international competition. The most influential line of literature in institutional comparison over the last fifteen years was the school of varieties of capitalism (VoC). Peter A. Hall and David Soskice (2001) published their volume of studies titled Varieties of Capitalism. The Institutional Foundations of Comparative Advantage. In its introduction, they elaborated a new theoretical framework for the survey of developed national economies. They introduced the two ideal types of capitalism, the coordinated and liberal market economy through the cases of Germany and the U.S.

Another line of economic literature studies particularly the member states of the European Union. In the 1990s, increasing attention was drawn to the national differences experienced among EU member states. Here I note three frequently quoted works on this topic: Ebbinghaus (1999), Boeri (2002), and Sapir (2006) described and verified the Anglo-Saxon, Nordic, Continental and Mediterranean models empirically. This approach also ignores the CEE countries.

In the last two decades, several attempts have been made to compare CEE countries with the existing models, but these cover only a few countries, or the scope of the applied data and viewpoint is not as wide as in the case of the old capitalist countries (e.g., Blanke and Hoffmann, 2008; Buchen, 2007; Cernat, 2006; Csaba, 2009; Feldmann, 2007; Lane, 2007; King, 2007; Knell and Srholec, 2007; Mykhnenko, 2007; Schweickert et al., 2013).

Nölke and Vliegenhart (2009) prepare a thorough inventory of the attempts made so far in the framework of $\mathrm{VoC}$ to classify the market economies that have emerged in the transition countries. They note the discrepancy in these attempts because some studies have argued that the CEE countries converge towards the liberal model, while others claim that a convergence towards the coordinated 
market economy occurred. A third group regards these countries as the hybrid variation of the two models. Nölke and Vliegenhart (2009) argue that the contradictory results can be attributed to the premature, mechanistic application of quantitative approaches. In their study, they prove the existence of a new capitalism model, which they termed a dependent market economy, but their investigation covers Visegrád countries only. The authors derive all features of the dependent market economy model from the essential role of foreign capital, which has a huge impact on the system of corporate governance, industrial relations, education and training, as well as the innovation system. It is without doubt that the role of foreign direct investment (FDI) has its special features compared to the developed, old-market economies, and it has an explanatory power concerning the evolution and operation of the institutional system. However, in their study, the authors apply FDI unilaterally as a single universal explanatory factor. In comparison with the study and book by Bohle and Greskovits $(2007,2012)$, it is striking how important elements are left out from the attempt to understand the institutional systems of the countries concerned.

Bohle and Greskovits $(2007,2012)$ argue that after the fall of the socialist system, three versions of capitalism emerged in Central and Eastern Europe: a purely neoliberal type in the Baltic states, an "embedded" neoliberal type in the Visegrád countries and a neo-corporatist system in Slovenia. When creating these types, the authors address new aspects, not those described so far. In addition to the usually examined fields of the welfare state and labor relations, industrial structural change, macroeconomic stability and even the dynamism of the political systems were subject to scrutiny. When compared to the studies above, an additional originality these authors bring to the discussion has to do with the fact that they take the specific features of the socialist legacies into account and, starting from here, present the evolution of the models from a historical perspective. In addition, they integrate the impacts of the EU and the transnational companies into their explanation. 
In this paper, I rely on my empirical investigation which describes a distinct model of capitalism of the CEE countries within the EU. Although, as Bohle and Greskovits (2012) describe, there are significant differences among the CEE countries, there are also commonalities which distinguish them from the other types of capitalism in the EU (Farkas, 2011, 2016). ${ }^{1}$ According to this analysis, the characteristic features of the model are the following: modernization is built on FDI; the innovation system is weak; the financial system is bank-based; sustaining competitiveness is possible only through a liberalized labor market and low social expenditures; social partnership is weak; the trade union density is low; and employees are vulnerable. The elements of the CEE model can essentially be attributed to three factors: a shortage of capital and management skills, a weak civil society, and the impacts of the EU and international organizations on CEE countries. The shortage of capital and management skills made foreign investment a necessity, accompanied by immediate liberalization, without even a suggestion of the industrial protection measures customary in emerging countries at other times and in other regions. This result came from the economic paradigm prevailing in the western countries and the level of integration achieved by the old member states (OMS) of the EU. Shortage of capital made it a necessity for the financial system to be bank-based because a substantial part of the FDI was realized in the financial sector, that is, in banks. The functioning of the labor market and labor relations is different from that of the OMS due to the fact that civil society, specifically, unionization, is less effectual in CEE countries than in the OMS. Without the compulsion of EU legal harmonization, the position of employees would presumably be even weaker. A low or relatively high level of social protection and the suppression of welfare redistribution correlate well among the CEE member states with the relative strength or weakness of civil society and the depth of the roots and traditions of the institutions of social protection. The system of research, development and innovation (R\&D\&I) is also easy to understand, given the lack of a domestically-based, internationallycompetitive corporate sector, which drives the innovation system in the Nordic,

1 See detailed arguments on the distinct model in Farkas (2016). 
north-western countries. Nowhere can state-induced research and development (R\&D) compensate for this lack. To sum up, the CEE model did not emerge arbitrarily but as a response to the starting conditions - it cannot be regarded as a transitional state that will automatically progress toward some other European model of capitalism, and one could surmise that this institutional arrangement might be capable of reproducing itself.

The complementarity between the elements of the institutional arrangement described in the foregoing certainly suggests the likelihood of the model's sustainability. The capital flowing into less developed countries seeks out relatively cheap but suitably skilled labor and this attraction can be retained with a liberalized labor market. The survival of the liberalized labor market is assisted by weak unionization, but the former also limits the strengthening of trade unions. The lower productivity resulting from the underdeveloped domestic economy and the lower added value of the production conducted at foreign corporations permit a relatively low level of investment in human capital both in education and in the social services. This result, however, not only makes the residual welfare state durable but also limits the development of R\&D\&I systems, which, in turn, maintains the asymmetric dependence on the OMS and the highly developed countries in general. This type of institutional complementarity can be dismantled if the FDI can fulfill the role that economists expected of it at the time of change in the political system, in other words, if the spillover effect enables the domestic economy to converge with that of the highly developed countries in terms of productivity. There are possibilities of upgrading along the value chain for both subsidiaries and domestic suppliers, but the outlook on upgrading experiences in CEE is very mixed (see, e.g., Éltető, Magasházi and Szalavetz, 2015).

Overall, on the one hand, the development model of the CEE countries undoubtedly led to successes. Even in the unfavorable global economic situation, the pace of growth is slower, but in this region-unlike in the Mediterranean region-convergence continues in the majority of the countries (Table 1). On 
the other hand, it is clear from the foregoing that the features of the current CEE model do not support the prevalent thinking that the new, post-socialist member states are on a development path that differs from the OMS only in quantitative terms and that convergence is only a matter of time. Table 1 also shows that the non-EU member WB countries, which started from a low base line at the beginning of the 2000s, have made very little progress in convergence toward the EU average GDP level. This begs the question of whether this lag has institutional or other reasons.

Table 1: Economic Performance of the CEE EU Member States and the WB Countries in GDP Per Capita

\begin{tabular}{|c|c|c|c|c|c|}
\hline $\begin{array}{l}\text { Real GDP } \\
1989=100\end{array}$ & \multicolumn{4}{|c|}{$\begin{array}{c}G D P \text { per capita in PPS } \\
E U-28=100\end{array}$} & $\begin{array}{l}\text { Convergence to } \\
\text { EU average in pp }\end{array}$ \\
\hline $2003^{*}$ & $2004^{* *}$ & 2008 & 2009 & 2014 & $2004-2014$ \\
\hline
\end{tabular}

\section{EU member states}

\begin{tabular}{|c|c|c|c|c|c|c|}
\hline Estonia & 104.9 & 55 & 68 & 62 & 76 & 21 \\
\hline Latvia & 87.9 & 47 & 60 & 53 & 64 & 17 \\
\hline Lithuania & 86.7 & 50 & 63 & 56 & 75 & 25 \\
\hline Poland & 134.5 & 49 & 54 & 59 & 68 & 19 \\
\hline Czech Republic & 107.4 & 79 & 81 & 83 & 85 & 6 \\
\hline Slovakia & 114.2 & 56 & 72 & 71 & 77 & 21 \\
\hline Hungary & 115.3 & 62 & 63 & 64 & 68 & 6 \\
\hline Slovenia & 119.5 & 86 & 89 & 85 & 83 & -3 \\
\hline Croatia & 91.2 & 57 & 63 & 62 & 59 & 2 \\
\hline Romania & 92.6 & 34 & 48 & 49 & 55 & 21 \\
\hline Bulgaria & 87.0 & 35 & 44 & 45 & 47 & 12 \\
\hline \multicolumn{7}{|l|}{ Western Balkan countries } \\
\hline Montenegro & 50.1 & 30 & 41 & 40 & 41 & 11 \\
\hline FYR Macedonia & 81.4 & 27 & 33 & 35 & 37 & 10 \\
\hline Albania & 123.6 & 22 & 26 & 29 & 30 & 8 \\
\hline Serbia & 50.1 & 32 & 36 & 36 & 37 & 5 \\
\hline Bosnia and Herzegovina & $:$ & 24 & 27 & 28 & 29 & 5 \\
\hline
\end{tabular}

Notes: ${ }^{*}$ Due both to the quality of the statistical data from that time and to the quality of the commodities making up GDP back then, this comparison is suitable only as a very approximate guide. ${ }^{* *}$ Data are available for Montenegro, FYR Macedonia, Albania, Serbia, and Bosnia and Herzegovina from 2005; data are not available for Kosovo.

Source: Author's construction based on Eurostat online databases and UNECE (2004: 80). 
In many cases, data on WB countries are missing, which hinders the performance of a cluster analysis to compare these countries to the CEE countries. Thus, I use descriptive statistics. In the comparison it is reasonable to scrutinize the achievement of three subgroups of the CEE model: the Baltic states (Estonia, Latvia, and Lithuania), the Visegrád countries (Poland, the Czech Republic, Slovakia, and Hungary), Slovenia (CEE5), and Bulgaria and Romania (SEE2). Due to its later EU accession, Croatia is shown separately. Not only do institutional analyses support this distinction (e.g., Bohle and Greskovits, 2012), but recent research applies CEE5 as a reference group (Gabrisch et al., 2015; Murgasova et al., 2015). Despite its special characteristics, Slovenia is closer to Visegrád countries than to others. The Baltics consists of small market-sized economies, which are comparable to the WB countries in this respect, apart from Serbia. The comparison to SEE2 may indicate the impact of the common legacy of the Balkan countries. The data of non-EU member WB countries are not aggregated because their differences may be interesting. Croatian experts emphasize that in spite of seven decades of common history and institutional systems, their economies have become different very soon after the dissolution of Yugoslavia (Bićanić, Deskar-Škrbić and Zrnc, 2016).

\section{Transformation of the Product Markets, the Innovation System and the Financial System}

It is generally accepted that in the CEE countries, transformation FDI inflows accompanying privatization played an outstanding role. These countries have benefited from the integration into global supply chains - especially the Visegrád countries - and by being part of the German supply chain in machinery and transport equipment sectors, they have become export-driven, open economies. Estrin and Uvalic (2013) find a different role of FDI in the WB countries. On the one hand, due to lower national savings and investment in these countries (and SEE2), FDI has a much more significant contribution to the gross fixed capital 
formation in the Balkans than in the CEE5 and Baltic states. On the other hand, even taking into account the greater distance to the major investor countries, the WB countries have received less FDI than the EU members, especially the nonBalkans. Table 2 also shows an ambiguous situation. The average inward FDI stock as a percentage of GDP is not lower in the WB countries when compared to other country groups of CEE EU members. However, the per capita inward FDI stock is much lower and the WB countries remained significantly less open economies in terms of exports than the EU members. It suggests that the business environment is not able to attract and to absorb more FDI.

Table 2: Trade Openness and the Inward FDI Stock

\begin{tabular}{|c|c|c|c|c|c|}
\hline & $\begin{array}{l}\text { Exports of } \\
\text { goods and } \\
\text { services, in } \\
\% \text { of } G D P\end{array}$ & $\begin{array}{c}\text { Inward } \\
\text { FDI stock, } \\
\text { as a \% of } \\
\text { GDP }\end{array}$ & $\begin{array}{c}\text { Inward } \\
\text { FDI stock } \\
\text { per capita, } \\
\text { in EUR }\end{array}$ & $\begin{array}{c}\text { Share of } \\
\text { manufacturing } \\
\text { as a \% of } \\
\text { inward FDI } \\
\text { stock }\end{array}$ & $\begin{array}{c}\text { High-tech } \\
\text { medium } \\
\text { bigh-tech } \\
\text { export* }\end{array}$ \\
\hline & 2014 & 2013 & 2013 & 2012 & 2013 \\
\hline Baltic states average & 74.8 & 56.4 & 7,262 & 17.7 & 34.7 \\
\hline CEE5 average & 77.8 & 57.0 & 7,099 & 30.1 & 59 \\
\hline SEE2 average & 53.1 & 69.3 & 4,168 & 24.4 & 38.7 \\
\hline Croatia & 46.3 & 54.3 & 5,529 & 26.8 & 37.6 \\
\hline Albania & 28.1 & 37.6 & 1,309 & 25.5 & 4 \\
\hline Bosnia and Herzegovina & n.a. & 44.7 & 1,563 & 30.6 & 19 \\
\hline Kosovo & 19.6 & 53.3 & 1,517 & n.a. & 7 \\
\hline FYR Macedonia & 47.8 & 52.1 & 1,929 & 29.9 & 27 \\
\hline Montenegro & 40.1 & 116.9 & 6,290 & n.a. & 11 \\
\hline Serbia & 43.4 & 66.3 & 2,956 & n.a. & 32 \\
\hline
\end{tabular}

Note: * The source of the EU members data is the European Commission (2015c), the others' source is Gabrisch et al. (2015). European Commission (2015c) publishes a higher value of high-tech and medium high-tech export for FYR Macedonia (45.6 percent) and Serbia (41.1 percent).

Source: Author's construction based on European Commission (2015c: 82-83), Eurostat online databases, Gabrisch et al. (2015: 75), and Hunya (2014: 35, 39, 51-52).

The share of manufacturing in FDI stock is not smaller in the WB countries where data are available, than in the EU members (Table 2). However, the composition of FDI in manufacturing is less advantageous than in the CEE5 countries. Tables 2 and 3 clearly show that FDI has gone to manufacturing sectors of lower 
value added products, which is reflected in the smaller ratio of high-tech and medium high-tech exports. In addition, the capital inflows followed the Baltic patterns, and FDI was directed into non-tradable sectors rather than tradable sectors (Murgasova et al., 2015: 48).

Table 3: Inward FDI Stock by Top 3 Economic Activities, in 2012

\begin{tabular}{|c|c|c|}
\hline & Top 3 activities in inward FDI stock & Top 3 activities within manufacturing \\
\hline \multirow{3}{*}{ Croatia } & Financial intermediation & $\begin{array}{l}\text { Coke, refined petroleum products, } \\
\text { and nuclear fuel }\end{array}$ \\
\hline & Manufacturing & $\begin{array}{l}\text { Chemicals, chemical products, } \\
\text { and man-made fibers }\end{array}$ \\
\hline & $\begin{array}{l}\text { Real estate, renting, and } \\
\text { business activities }\end{array}$ & Other non-metallic mineral products \\
\hline \multirow{3}{*}{ Albania } & Manufacturing & $\begin{array}{l}\text { Other, not elsewhere classified } \\
\text { industries }\end{array}$ \\
\hline & Mining and quarrying & Other non-metallic mineral products \\
\hline & Financial intermediation & Food products, beverages, and tobacco \\
\hline \multirow{3}{*}{$\begin{array}{l}\text { Bosnia and } \\
\text { Herzegovina }\end{array}$} & Manufacturing & $\begin{array}{l}\text { Coke, refined petroleum products, } \\
\text { and nuclear fuel }\end{array}$ \\
\hline & Financial intermediation & Food products, beverages, and tobacco \\
\hline & $\begin{array}{l}\text { Real estate, renting, and } \\
\text { business activities }\end{array}$ & Other non-metallic mineral products \\
\hline \multirow{3}{*}{ FYR Macedonia } & Manufacturing & $\begin{array}{l}\text { Basic metals, fabricated metal products, } \\
\text { except machinery and equipment }\end{array}$ \\
\hline & Financial and insurance activities & Transport equipment \\
\hline & $\begin{array}{l}\text { Wholesale, retail trade, repair of motor } \\
\text { vehicles etc. }\end{array}$ & $\begin{array}{l}\text { Food products, beverages, and tobacco } \\
\text { products }\end{array}$ \\
\hline
\end{tabular}

Note: Data are not available for Kosovo, Montenegro, and Serbia.

Source: Author's construction based on Hunya $(2014: 58,97,99,101)$.

Services have an approximately 70 percent share in the gross value added in both the EU members and the WB countries. Although the export of services-seen as a percentage of GDP-is higher in the WB countries when compared to the CEE5 countries, and although their trade balance is positive, they cannot offset the deficit of trade of goods. The most significant activities of service exports are tourism and transport (Gabrisch et al., 2015: 86-93). 
The difference between the EU members and WB countries is pronounced in their economic structures in terms of gross value added by the other two sectors. Whereas the share of industry in gross value added is lower in Albania, FYR Macedonia, and Montenegro, even in the Baltics, agriculture, forestry, and fisheries represent a substantially higher share in the WB countries than in the EU members (Table 4).

Table 4: Gross Value Added by Sector, in \%

\begin{tabular}{l|c|c}
\cline { 2 - 3 } & $\begin{array}{c}\text { Agriculture, } \\
\text { forestry, and fisheries }\end{array}$ & Industry \\
\cline { 2 - 3 } Baltic states average & 4.1 & 21.5 \\
\hline CEE5 average & 3.4 & 27.0 \\
\hline SEE2 average & 5.6 & 29.7 \\
\hline Croatia & 4.4 & 21.0 \\
\hline Albania & 22.5 & 14.4 \\
\hline Bosnia and Herzegovina & 8.0 & 21.6 \\
\hline Kosovo & 14.4 & 20.3 \\
\hline FYR Macedonia & 11.0 & 17.9 \\
\hline Montenegro & 9.8 & 13.8 \\
\hline Serbia & 9.4 & 26.6 \\
\hline
\end{tabular}

Source: Author's construction based on Eurostat online databases and European Commission (2015a: 77; 2015b: 67; 2015d: 65; 2015e: 79; 2015f: 76; 2015g: 77).

Considering the economic structure and the composition of FDI, it is not surprising that gross domestic expenditures on $\mathrm{R} \& \mathrm{D}$ in the WB are well below the level of the Baltic states and CEE5 countries (Table 5). Even these data are uncertain in some WB countries and only Serbia and Macedonia are involved in the European Innovation Scoreboard analyzing the performance of their innovation systems. Serbia belongs to the group of moderate innovators and Macedonia to the modest innovators (European Commission, 2015c). However, it is more encouraging that 18 percent of firms are engaged in either product or/and process innovation, and 29 percent in organizational or/and marketing innovation (Sanfey, Milatović and Krešić, 2016: 33). 
Table 5: Indicators of Business Environment and $R \& D$ Expenditure

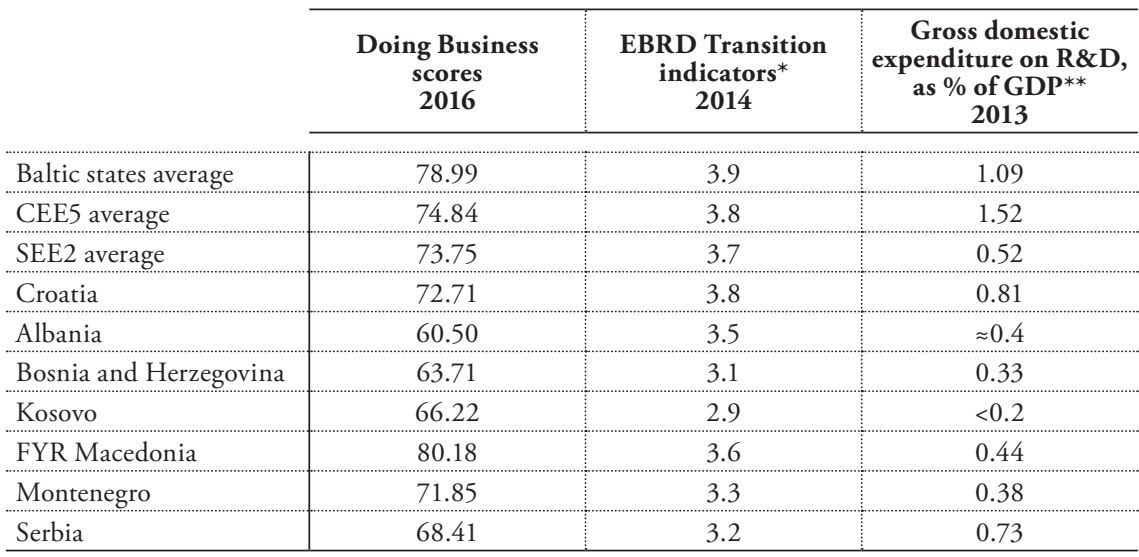

Notes: * The measurement scale for the indicators ranges from 1 to $4+$, where 1 represents little or no change from a rigid centrally-planned economy, and 4+ represents the standards of an industrialized market economy. The Czech Republic and Estonia are not assessed. ** The source of the data for the EU members, Montenegro, and Serbia is the Eurostat database, and European Commission reports for all other countries.

Source: Author's construction based on EBRD's online databases, Eurostat online databases, European Commission (2015a: 66; 2015b: 70; 2015d: 47; 2015g: 80), and World Bank (2016a: 5).

As we have seen above, the scale of FDI inflows indicates that the business environment in the WB countries has not sufficiently developed yet. Their World Bank's Doing Business scores have increased, but they are lower than the EU members' scores, with the exception of FYR Macedonia. These scores measure how easy it is to do business, and this ranking does not comply fully with the EBRD transition indicators, which measure the progress of privatization and liberalization reforms (Table 5). The price and trade liberalization is completed in each WB country, but many inefficient state-owned enterprises with weak governance remain to be privatized. The indicator of large scale privatization is equal or below 3 in Bosnia and Herzegovina, Kosovo, and Serbia, and the indicator of governance and enterprise restructuring is between 2 and 2.7 in each country.

Financial sectors underwent significant transformation in the WB countries prior to the 2008 global crisis. The new institutional setting is very similar to 
the CEE financial systems. Financial deepening has been driven by FDI, and the banking system has been dominated by foreign owners. Financial systems are bank-based, and the role of financial markets in funding is meager (Table 6). The assets of investment, insurance, and pension funds are less than 20 percent of the assets of the financial sectors in WB countries (Gabrisch et al., 2015: 43). In the aftermath of the crisis, the slowdown of economic growth and credit demand affected both the banking sector and stock market capitalization. The deleveraging process has decreased the banks' assets, and the rate of stock market capitalization has also diminished, but the institutional system remains unchanged. The monetary regimes of the Balkan countries are just as different as those of the EU members: Montenegro and Kosovo unilaterally adopted the euro; Croatia and Serbia introduced a managed float; Macedonia pegs against the euro; Bosnia and Herzegovina has a currency board; Albania adopted a floating exchange rate (EBRD online databases).

Table 6: Some Important Indicators of the Financial System

\begin{tabular}{|c|c|c|c|c|c|}
\hline & \\
\hline & $\begin{array}{c}\text { Deposit } \\
\text { money banks' } \\
\text { assets to } \\
G D P^{*} \text {, in \% }\end{array}$ & $\begin{array}{c}\text { Foreign bank } \\
\text { assets among } \\
\text { total bank } \\
\text { assets }^{* *} \text {, in } \%\end{array}$ & $\begin{array}{c}\text { Bank } \\
\text { deposits to } \\
G D P, \text { in } \%\end{array}$ & $\begin{array}{l}\text { Private credit by } \\
\text { deposit money } \\
\text { banks and } \\
\text { other financial } \\
\text { institutions to } \\
\text { GDP*, in } \%\end{array}$ & $\begin{array}{l}\text { Stock market } \\
\text { capitalization } \\
\text { to GDP, in } \%\end{array}$ \\
\hline & 2013 & 2013 & 2013 & 2013 & 2012 \\
\hline Baltic states average & 75.9 & 82 & 42.6 & 72.2 & 7.1 \\
\hline CEE5 average & 72.0 & 66 & 55.6 & 57.1 & 16.3 \\
\hline SEE2 average & 58.2 & 71 & 50.5 & 52.9 & 11.9 \\
\hline Croatia & 97.5 & 90 & 68.7 & 69.9 & 37.0 \\
\hline Albania & 62.7 & 81 & 68.9 & 37.7 & n. a. \\
\hline $\begin{array}{l}\text { Bosnia and } \\
\text { Herzegovina }\end{array}$ & 59.5 & 86 & 46.5 & 51.9 & n. a. \\
\hline Kosovo & 32.8 & n. a. & 37.7 & 35.1 & n. a. \\
\hline FYR Macedonia & 55.5 & 66 & 53.3 & 47.8 & 5.8 \\
\hline Montenegro & 61.4 & 89 & 50.1 & 53.3 & 85.8 \\
\hline Serbia & 60.7 & 74 & 42.9 & 48.2 & 17.7 \\
\hline
\end{tabular}

Notes: * Data are available for Bulgaria, the Czech Republic, Hungary, Latvia, Lithuania, and Poland from 2008; for Croatia from 2012; for Kosovo from 2011. ${ }^{* *}$ Data are available for Lithuania, Hungary, Poland, and Romania from 2012.

Source: Author's construction based on World Bank’s Global Financial Development online database. 
Although before the global crisis the banking systems of the WB countriesexcept for Montenegro - relied less on fast-moving wholesale funding than CEE EU members, the level of non-performing loans has increased more than in the CEE5. The Baltic states, which also reached a very high immediate post-crisis peak, were able to reduce the level of non-performing loans very soon due to comprehensive reforms. This comparison highlights the fact that in the WB countries, financial sectors require further reforms (Table 7). In the areas of supervision of financial institutions, crisis resolution, financial safety nets, and the introduction of the Basel Framework, WB countries have not kept pace with the CEE EU members. Furthermore, the strengthening of enforcement power is unavoidable (Murgasova et al., 2015).

Table 7: Transition Indicators of the Financial System

\begin{tabular}{|c|c|c|c|c|c|}
\hline & \\
\hline & Banking & $\begin{array}{l}\text { Insurance } \\
\text { and other } \\
\text { financial } \\
\text { services }\end{array}$ & $\begin{array}{l}\text { MSME } \\
\text { finance }\end{array}$ & $\begin{array}{l}\text { Private } \\
\text { equity }\end{array}$ & $\begin{array}{l}\text { Capital } \\
\text { markets }\end{array}$ \\
\hline Baltic states average & 3.3 & $3+$ & 3 & 2.3 & 3 \\
\hline CEE5 average & 3.5 & $3+$ & 3.2 & 2.7 & 3.2 \\
\hline SEE2 average & 3 & $3+$ & 3 & $3-$ & $3-$ \\
\hline Croatia & $3+$ & $3+$ & $3-$ & $2+$ & $3+$ \\
\hline Albania & $3-$ & 2 & $3-$ & 1 & 2 \\
\hline Bosnia and Herzegovina & $3-$ & $2+$ & $2+$ & $2-$ & 2 \\
\hline Kosovo & $2+$ & 2 & $3-$ & 1 & 1 \\
\hline FYR Macedonia & $3-$ & $3-$ & 3 & 1 & $2-$ \\
\hline Montenegro & $3-$ & $2+$ & 3 & 1 & 2 \\
\hline Serbia & $3-$ & 3 & 3 & 2 & 2 \\
\hline
\end{tabular}

Note: The measurement scale for the indicators ranges from 1 to $4+$, where 1 represents little or no change from a rigid centrally-planned economy and 4+ represents the standards of an industrialized market economy. The Czech Republic is not assessed. MSME: micro, small, and medium enterprise.

Source: Author's construction based on EBRD (2015: 91).

The 2011 euro zone crisis and the following risk aversion induced a new wave of deleveraging from the region. The Vienna II initiative launched in March 2012 could have decelerated but not prevented the withdrawal of funds from the region. Between 2011 and 2014, the Western Balkans lost around eight percent 
of the region's GDP in external bank funds. This loss was smaller in comparison to the eleven CEE EU member states, where it amounted up to 18 percent of the region's GDP. The restructuring continues for several global banking groups operating in the region though on a smaller scale than earlier (Sanfey, Milatović and Krešić, 2016: 36).

\section{Labor Market Performance, Industrial Relations, Social Protection and the Education System}

The most critical issue of the WB countries' transformation is the performance of labor markets. Unemployment rates were high even in the boom years of the 2000s, and the increase of unemployment exceeded the contraction of GDP through the years of global crisis, with the unemployment rates of 2014 remaining around the level of 2000 (see Table 8 and Gligorov, Ognjenović and Vidovic, 2011: 78). The difference in unemployment rates is enormous between the WB countries and EU members (with the exception of Croatia), and in youth unemployment the difference is dramatic. In such cases a rigid labor regulation usually hinders better outcomes. However, in general, the employment protection regulation (EPL) composite indicators are not higher in the WB countries than in their EU member peers (Table 8). Some sub-indicators in some countries are relatively high but these cannot explain the poor labor market performance of the WB countries. As anecdotal evidence suggests, it is more likely that differences between legislated and actual practices continue to persist (Kovtun et al., 2014). Furthermore, during the crisis, most countries resorted to passive measures to address rising unemployment or to prevent it. Despite governmental efforts, active labor market policy instruments are less used (Alishani, Shabani and Gjonbalaj, 2013).

Wages grew rapidly before the global crisis and productivity gains did not keep up with wage increases. Since the onset of the crisis, Albania has experienced 
a downward wage adjustment similar to the Baltic states. In Bosnia and Herzegovina the unit labor cost has decreased due to productivity growth, and Serbia has improved its wage competitiveness through currency depreciation. In Montenegro, wages continued to outpace productivity. Similarly, there is no general trend in minimum wages and tax wedges. While in some WB countries minimum wages are higher when compared with their peer counterparts, in some other countries the tax wedges are higher (Kovtun et al., 2014). To sum up, labor costs can contribute to poor labor market performance but are not the main factors triggering them.

Table 8: Some Important Labor Market Indicators

\begin{tabular}{|c|c|c|c|c|c|}
\hline & 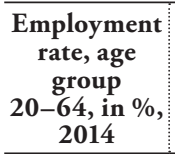 & $\begin{array}{c}\text { Unemployment } \\
\text { rate, age group } \\
15-74, \text { in } \%, \\
2014\end{array}$ & $\begin{array}{c}\text { Youth } \\
\text { unemployment } \\
\text { rate, age group } \\
15-24 \text {, in \%, } \\
2014 \\
\end{array}$ & $\begin{array}{c}\text { EPL } \\
2007\end{array}$ & $\begin{array}{c}\text { Personal } \\
\text { remittances, } \\
\text { received, in \% } \\
\text { of GDP, } \\
2014\end{array}$ \\
\hline Baltic states average & 72.2 & 9.6 & 17.9 & 2.5 & 4.1 \\
\hline CEE5 average & 68.0 & 9.1 & 22.0 & 2.0 & 1.9 \\
\hline SEE2 average & 65.4 & 9.1 & 23.9 & 2.4 & 2.4 \\
\hline Croatia & 59.2 & 17,3 & 45.5 & 2.7 & 3.8 \\
\hline Albania & 56.6 & 17.5 & 39.0 & 2.1 & 8.6 \\
\hline Bosnia and Herzegovina & 43.2 & 27.6 & 62.7 & 2.6 & 11.4 \\
\hline Kosovo & 31.3 & 35.3 & 61.0 & 2.5 & n. a. \\
\hline FYR Macedonia & 51.3 & 28.0 & 53.1 & 3.1 & 3.2 \\
\hline Montenegro & 55.6 & 18.0 & 35.8 & 2.2 & 9.4 \\
\hline Serbia & 53.5 & 18.9 & 47.1 & 2.2 & 8.4 \\
\hline
\end{tabular}

Note: EPL for EU member states and Kosovo is available from the early 2000s.

Sources: Eurostat online databases, European Commission (2015a: 79; 2015b: 69; 2015d: 66; 2015e: 81; 2015f: 78; 2015g: 79), Gabrisch et al. (2015: 111), Kogan, Gebel and Noelke (2008: 55), and World Bank's online databases.

It seems to be more important that due to the delayed transition, diversification from traditional sectors and private sector job creation is still lagging compared to CEE EU members. As a consequence of the weak functioning of formal sectors, vast informal sectors have developed. The estimates of informality (and the used methodologies) vary. Schneider, in collaboration with A.T. Kearney and Visa (2013: 4) suggests that the informal (shadow) economy accounts for 20 percent 
of GDP in CEE5, 27 percent in the Baltics, and 30 percent in the SEE2. The European Commission (2008: 43) and Arandarenko and Bartlett (2012: 122) accept that about one third of the GDP is being produced informally in the WB countries, and, in some cases, such as in Kosovo, Albania and FYR Macedonia, that share is even higher. In terms of employment, the informal sectors' share varies between 30 and 60 percent of total employment. Gabrisch et al. (2015: 105) refer to the $2012 / 2013$ data, which show an improving trend in Serbia and FYR Macedonia with 19.3 and 22.5 percent informal employment, respectively.

The striking difference between the CEE EU members and the WB countries is the level of remittance inflows as percentage of GDP (Table 8), which is very high in the WB countries despite the decrease during the crisis years (Bartlett and Prica, 2012: 15). This difference influences the behavior of employees because these transfers can allow job seekers to extend the period of job search and increase reservation wages. In addition, large-scale migration is associated with the brain drain (Kovtun et al., 2014).

Industrial relations in $\mathrm{WB}$ countries resemble those of $\mathrm{CEE} \mathrm{EU}$ members. Although trade union density is higher than in the Baltics and CEE5 (Table 9), it is due to strong union presence in public sectors. Trade union density is low in the private sector, thus the trade unions' bargaining power has declined. The inherited centralized organization systems have become more fragmented. Collective bargaining is largely dominated by company agreements. In most countries, except in Bosnia and Herzegovina and Kosovo, a council for tripartite consultations exists, but in many cases only on paper (European Commission, 2008; Kohl, 2010). The self-management system of the former Yugoslavia has not been transformed to social partnership in a market economy. According to the Global Competitiveness Index (GCI), executive opinion surveys reflect low levels of cooperation in labor-employer relations, except in Albania and FYR Macedonia (Table 9). 
A comparison of social protection systems is much more difficult to draw than that of the above analyzed areas due to an almost complete lack of comparable data. As in many CEE countries, in the WB countries Bismarck's legacy of social insurance, which was delivered by the Austro-Hungarian Empire and the Kingdom of Yugoslavia, was incorporated in the welfare system of the communist regime. The system covered a range of social risks but in a dual structure, only those employed in the socialist industrial sector received workbased benefits, while others (e.g., small farmers, professionals such as lawyers etc.) could access a voluntary insurance scheme. In Albania, the social insurance system was established for the first time in 1991. The transformation since the 1990s has not resulted in a single "Western Balkan way" but in a variety of social protection systems (Bartlett, 2012; European Commission, 2009). The recession of transformation, wars and conflicts eroded the economic basis of social services and transfers. Furthermore, the social consequences of the 2008 global crisis were especially severe in the region (Bartlett and Uvalic, 2013). It is not easy to compare the current level of social inequalities and poverty between the CEE EU members and the WB countries. According the GINI index, social inequalities are higher than in the CEE5 countries but similar to those of the Baltics and SEE2. The share of population which lives below a 5 USD threshold (measured at PPP) is very different among the WB countries, and the dataeven if reliable-are collected from various years. The data of Eurostat on the share of people at risk of poverty or social exclusion are gathered from the same year using the same methodology, but Serbia and FYR Macedonia are the only non-EU members which have the available data. The latter data suggest that the extension of poverty or social exclusion is similar to SEE2 countries but substantially higher than in the Baltics and CEE5 countries. The comparison of social protection expenditure is also only an estimate. IMF data on the general governments' social benefit expenditures are not available for three WB countries. The Eurostat data on social protection expenditures include the activities of both the public and private bodies (non-profit institutions serving households), but in four WB countries there are only earlier data on public expenditures (Table 9). 
Table 9: Some Indicators of Industrial Relations and Social Protection

\begin{tabular}{|c|c|c|c|c|c|c|c|}
\hline & $\begin{array}{c}\text { Trade } \\
\text { union } \\
\text { density, } \\
\text { in } \%\end{array}$ & $\begin{array}{c}\text { Cooperation } \\
\text { in } \\
\text { labor- } \\
\text { employer } \\
\text { relations, } \\
\text { GCI score }\end{array}$ & $\begin{array}{l}\text { GINI } \\
\text { index }\end{array}$ & $\begin{array}{c}\text { Absolute } \\
\text { poverty } \\
\text { at5USD } \\
\text { PPP per } \\
\text { day, \% of } \\
\text { population }\end{array}$ & $\begin{array}{c}\text { People } \\
\text { at risk of } \\
\text { poverty } \\
\text { or social } \\
\text { exclusion } \\
\text { in } \%\end{array}$ & $\begin{array}{c}\text { Expenditure } \\
\text { on } \\
\text { social } \\
\text { protection, } \\
\% \text { of GDP }\end{array}$ & $\begin{array}{c}\text { Social } \\
\text { benefits, } \\
\% \text { of GDP }\end{array}$ \\
\hline & 2008 & 2015 & $2014^{*}$ & $\begin{array}{l}\text { Latest data } \\
\text { before } \\
2010^{* *}\end{array}$ & 2014 & $2013^{* * *}$ & 2013 \\
\hline $\begin{array}{l}\text { Baltic states } \\
\text { average }\end{array}$ & 12 & 4.7 & 35.3 & 15.0 & 28.7 & 14.8 & 13.9 \\
\hline CEE5 average & 21 & 4.2 & 26.9 & 13.5 & 22.0 & 20.4 & 17.6 \\
\hline SEE2 average & 27 & 4.0 & 35.0 & 32.5 & 40.2 & 16.2 & 13.2 \\
\hline Croatia & 33 & 3.6 & 30.2 & 2.0 & 29.3 & 21.7 & 18.1 \\
\hline Albania & 23 & 5.0 & 29.0 & 33.4 & n. a. & 6.7 & 9.3 \\
\hline $\begin{array}{l}\text { Bosnia and } \\
\text { Herzegovina }\end{array}$ & 30 & 3.5 & 36.2 & 8.0 & n. a. & 15.1 & 15.8 \\
\hline Kosovo & $20-25$ & n. a. & n. a. & 82.0 & n. a. & $14-17$ & n. a. \\
\hline $\begin{array}{l}\text { FYR } \\
\text { Macedonia }\end{array}$ & 30 & 4.4 & 35.2 & 37.0 & 43.2 & n. a. & n. a. \\
\hline Montenegro & 35 & 3.9 & 26.2 & 49.2 & n. a. & 12.7 & n. a. \\
\hline Serbia & 33 & 3.4 & 38.6 & 17.1 & 43.1 & 23.3 & 19.5 \\
\hline
\end{tabular}

Notes: * Data are available for Albania from 2012, for Bosnia and Herzegovina from 2007, and for Montenegro from 2013. ${ }^{* *}$ Data are not available for the Czech Republic, Lithuania, Slovakia, and Slovenia. ${ }^{* * *}$ Data are available for public expenditures in the case of Albania from 2005, of Bosnia and Herzegovina from 2006, of Montenegro from 2007, and excluding health expenditures, of Kosovo from 2007. EU definition of social protection encompasses interventions from both public and private bodies.

Source: Author's construction based on European Commission (2009: 44-45; 2015e: 82), Eurostat online databases, IMF's Government Finance Statistics online database, Kohl (2010: 6, 11), Schwab and Sala-i-Martin (2015), UNUWIDER (2015), and World Bank (2010).

With the exception of Kosovo, which has introduced universal social benefits, other WB countries maintain the social insurance schemes accompanied by lowlevel social expenditures. This institutional arrangement is also typical in the

2 This indicator corresponds to the sum of persons who are at risk of poverty, severely materially deprived or living in households with very low work intensity. Persons are only counted once even if they are present in several sub-indicators. At risk of poverty are persons with an equivalized disposable income below the risk-of-poverty threshold, which is set at 60 percent of the national median equivalized disposable income (after social transfers). Material deprivation covers indicators related to economic strain and durables. Severely materially deprived persons have living conditions severely constrained by a lack of resources, they experience at least four of the following nine deprivation items: cannot afford: (i) to pay rent or utility bills; (ii) keep their home adequately warm; (iii) face unexpected expenses; (iv) eat meat, fish or a protein equivalent every second day; (v) a week holiday away from home; (vi) a car; (vii) a washing machine; (viii) a color TV; or (ix) a telephone. People living in households with very low work intensity are those aged 0-59 living in households where the adults (aged 18-59) have worked less than 20 percent of their total work potential during the past year. 
CEE EU members. The social insurance system in Albania is associated with residual means-tested social assistance for those not covered by social insurance and extremely low expenditures. In the other WB countries, the social assistance benefits are targeted at politically influential groups such as the veterans of $1990 \mathrm{~s}$ wars and pensioners, and the systems have become fragmented and discretionary with very little impact on poverty. Due to low formal employment, large informal economies, emigration, and ageing societies, WB countries are forced to reduce public pension spending, which exceeds the level of CEE EU members' average-except in Albania and Kosovo. The introduced pension reforms widely varied in their structure and scope (Bartlett, 2012; European Commission, 2009; Murgasova et al., 2015). Strong status preservation is similar to that of the CEE5 systems.

Unlike other institutional areas, the educational system has no elaborated models in the literature on institutional comparison of socio-economic systems, and there are few obtainable indicators which could support a well comparison. Even the data, which reveal some elements of educational systems, are incomplete concerning Bosnia and Herzegovina, Kosovo, FYR Macedonia, and Montenegro. The level of enrolment in primary and secondary education was high in the socialist countries in general. Similarly to most post-socialist countries, during the transition period, there was little investment in upgrading the educational systems. Therefore, in WB countries, the skills of the workforce have deteriorated despite the relatively advantageous inheritance from the previous system. ${ }^{3}$ Nowadays, Croatian students' performance is close to the results of the CEE5 countries, the Serbian results are closer to the SEE2 average. Both public expenditure and total enrolment in tertiary education are below the level of the Baltics and CEE5 (Table 10).

\footnotetext{
3 "By 1981, in Yugoslavia, illiteracy rates had fallen to $9.5 \%$ of the population, from $25.4 \%$ in 1948 , albeit with some regional differences, ranging from $0 \%$ in Slovenia and 5.6\% in Croatia to $14.5 \%$ in Bosnia and Herzegovina and $17.6 \%$ in Kosovo. The proportion attending high schools rose in the same period from $0.6 \%$ to $5.6 \%$, with much smaller regional variations" (European Commission, 2009: 9).
} 
Table 10: Some Indicators of the Educational System

\begin{tabular}{|c|c|c|c|c|c|}
\hline & \multirow{2}{*}{\multicolumn{3}{|c|}{ PISA results 2012}} & \multirow{3}{*}{$\begin{array}{c}\text { Public } \\
\text { expenditure } \\
\text { on education } \\
\text { as a \% of } \\
\text { GDP*, } 2011\end{array}$} & \multirow{3}{*}{$\begin{array}{c}\text { Total } \\
\text { enrolment } \\
\text { in tertiary } \\
\text { education, in } \\
\%^{* *}, 2013^{* *} \\
\end{array}$} \\
\hline & & & & & \\
\hline & Mathematics & Reading & Science & & \\
\hline Baltic states average & 497 & 494 & 513 & 5.09 & 71 \\
\hline CEE5 average & 495 & 488 & 503 & 4.78 & 66 \\
\hline SEE2 average & 442 & 437 & 443 & 3.44 & 59 \\
\hline Croatia & 471 & 485 & 491 & 4.21 & 62 \\
\hline Albania & 394 & 394 & 397 & 3.3 & 59 \\
\hline Bosnia and Herzegovina & n. a. & n. a. & n. a. & n. a. & n. a. \\
\hline Kosovo & n. a. & n. a. & n. a. & 4.4 & n. a. \\
\hline FYR Macedonia & n. a. & n. a. & n. a. & n. a. & 38 \\
\hline Montenegro & 410 & 422 & 410 & n. a. & n. a. \\
\hline Serbia & 449 & 446 & 445 & 4.3 & 56 \\
\hline
\end{tabular}

Notes: ${ }^{*}$ Data are available for Albania and Kosovo from 2014, and Serbia from 2013. ${ }^{* *}$ Total enrolment in tertiary education (ISCED 5 to 8), regardless of age, expressed as a percentage of the total population of the five-year age group following on from secondary school leaving. ${ }^{* * *} 2013$ or the latest available data.

Source: Author's construction based on European Commission (2015a: 80; 2015d: 67; 2015f: 79), Eurostat online databases, OECD (2014), and World Bank's online databases.

However, the real problems of educational systems are analyzed in county reports and in-depth case studies. Higher education reforms are marked by privatization, marketization, and introduction of the Bologna system. The insufficient capacity and financial resources of state universities have led to a boom in establishing private institutions. In 2010-2011, 47 state universities and 250 private institutions existed in the WB countries including Croatia. As a consequence, the organizations of higher education have become fragmented, the average student number in private universities has been around 500, and satisfactory quality assurance has not been solved yet. The largest share of students attending private universities can be found in Kosovo (37 percent), and the smallest in Croatia ( 6 percent). In addition to high tuition fees at private universities, a significant number of self-financing students at state universities also entails that education has become less accessible to the lower socio-economic classes, and this exacerbates inequality in education (Gabrisch et al., 2015: 112; Babović and Vuković, 2015: 22-24). 
Recently, vocational education and training has been given more attention all over in Europe in relation to economic competitiveness. Based on country case studies, Bartlett et al. (2014) report on different enrolment rates in WB countries: while the share of students following vocational programs is very low in Albania-Serbia, Croatia, and Montenegro have maintained their vocational system and have relatively high shares of students enrolled in vocational programs. According to this report, critical problems of vocational education are the poor teaching quality and the lack of appropriate skills taught in many vocational schools in the region.

The problems of both higher and vocational education are reflected in the skill mismatch which can be experienced in the labor markets of the WB countries (Arandarenko and Bartlett, 2012). This skill mismatch is another important factor explaining the persistently high unemployment rates.

\section{The Quality of Governance}

Recent institutional comparisons in the EU and the CEE countries have shown that the state plays a fundamental role not only in running social services and the educational system, but directly in the performance of the economic system. Therefore, the operation method of the state has to be integrated more organically into the models because the professionalism of regulation, the level of corruption, and other elements of good governance fundamentally affect the operation as well as the competitiveness of the institutional system of economy (Farkas, 2016; Szanyi, 2013).

The World Bank also has a research dataset-Worldwide Governance Indicators (WGI) - focusing on good governance in terms of both efficiency and rule of law. These data are gathered from a number of survey institutes, think tanks, non-governmental organizations, international organizations, and private sector firms. Although the composite indicators based on opinion surveys are "soft" data, we have no other comparable datasets. The Worldwide Governance 
Indicators project constructs aggregate indicators of six broad dimensions of governance: voice and accountability, political stability and absence of violence/ terrorism, government effectiveness, regulatory quality, rule of law, and control of corruption. The results of surveys are converted into a percentile ranking of all countries, in which the northern and north-western EU members are above 90 percent. The average value of the indicators of six broad dimensions of governance is between $70-80$ percent in the Baltics and CEE5 countries and below 60 percent in the Balkan countries, except in Croatia (Figure 1). This great difference suggests that the above outlined unfinished reforms in several areas are not only a consequence of delayed transformation but also that of the weaker administration capacity of the WB countries. However, the administration capacity depends also on transformation. Sanfey, Milatović and Krešić (2016: 6 , 29) display a close correlation between WGI and transition indicators in the CEE and WB countries. The latter made substantial progress between 2000 and 2014.

Figure 1: Worldwide Governance Indicators Ranking of the CEE EU Members and WB Countries in 2014

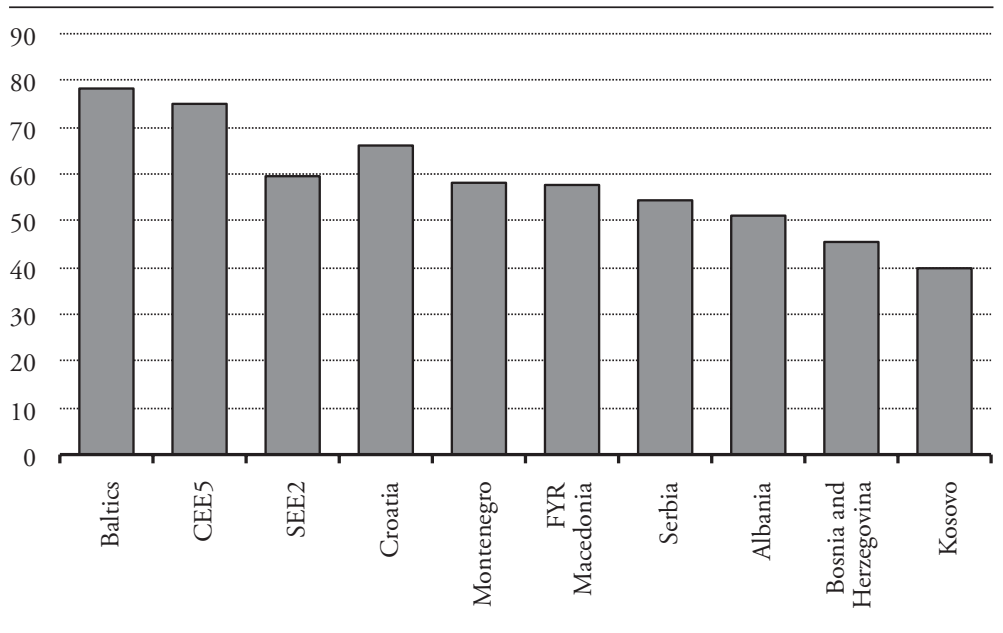

Source: Author's construction based on Kaufmann and Kraay (2015). 
The importance of governance is indicated by the fact that the key finding of the recent research of the Global Development Network Southeast Europe is "that processes of state-building and their failure have been mostly responsible for both spurs and failures of industrialization" (wiiw, 2016).

\section{Conclusion}

The comparison of institutional systems does not provide an unambiguous answer to the question of whether the Western Balkan market economies fit the capitalism model of the CEE EU members. FDI inflows have not modernized the economies of Western Balkans to the extent seen in the CEE EU members, and they have remained less open economies with weaker competition. However, this can partly be explained by the delayed and unfinished reforms and the differences between the two regions' product markets, which seem to be structural rather than the consequence of an alternative institutional arrangement. The delayed and unfinished product market reforms entail the poorer development level of innovation systems especially in the smaller WB countries. The financial systems in WB countries are strongly bank-based, dominantly foreign-owned, and the institutional difference in comparison with CEE EU members is seen in some uncompleted regulation reforms.

We can find more pronounced differences in institutional areas related to human capital. The extremely low formal employment, the extended informal employment, and the large share of remittances in personal incomes highlight not only parametric but institutional differences between the CEE EU members and the WB countries, which can, in turn, lead to different rules in the actors' behavior on labor markets. In contrast to labor markets, industrial relations follow basically similar patterns in the two regions. In the majority of WB countries, the basic elements of the social protection system, that is, the social insurance scheme with the-in European terms - low level of social expenditures, comply with the CEE model, but, as we have seen, there are unique features in the region. 
The available data does not allow an assessment of whether the differences in educational systems between the two regions are quantitative or qualitative, and the differences seem to be substantial even among the WB countries.

Differences in good governance are worrying, especially between the Baltics, CEE5 countries and the WB countries, because the achievement of all the above mentioned reforms depends on the administration capacities of the states.

The reform policy agendas in WB countries-partly induced by international and EU institutions - set the target for the achievement of further reforms, which would result in the CEE model of capitalism. Will such a model be realized or will the current differences be institutionalized, creating thereby a new normality, a new and a distinct model of capitalism, remains an open question.

\section{Literature}

Alishani, Anera, Ariana Shabani and Muje Gjonbalaj, 2013, "Labour Market Institutions in the Western Balkan Countries and their Economic Implications: Evidence for Kosova", Iliria International Review, 3(2), pp. 85-101. https://doi. org/10.21113/iir.v3i2.117

Arandarenko, Mihail and Will Bartlett, eds., 2012, Labour Market and Skills in the Western Balkans, Belgrade: FREN - Foundation for the Advancement of Economics.

Babović, Marija and Danilo Vuković, 2015, "Shaping Social Policies in the Western Balkans: Legal and Institutional Changes in the Context of Globalisation and Post-socialist Transformation" in Margo Thomas and Vesna Bojicic-Dzelilovic, eds., Public Policy Making in the Western Balkans, pp. 17-43, Dordrecht: Springer. 
Bartlett, Will, 2012, “The Political Economy of Welfare Reform in the Western Balkans" in Caterina Ruggeri Laderchi and Sara Savastano, eds., Poverty and Exclusion in the Western Balkans: New Dimensions for Measuring Poverty, pp. 245259, Berlin: Springer.

Bartlett, Will, Marina Cino Pagliarello, Claire Gordon and Simona Milio, 2014, South Eastern Europe, Israel and Turkey - Trends, Perspectives and Challenges in Strengthening Vocational Education for Social Inclusion and Social Cohesion, Luxembourg: Publications Office of the European Union.

Bartlett, Will and Ivana Prica, 2012, "The Variable Impact of the Global Economic Crisis in South East Europe”, LSEE Papers on South Eastern Europe, No. 4, April, London: LSEE - Research on South Eastern Europe.

Bartlett, Will and Milica Uvalic, eds., 2013, Social Consequences of the Global Economic Crisis in South East Europe, London: LSEE - Research on South Eastern Europe.

Bićanić, Ivo, Milan Deskar-Škrbić and Jurica Zrnc, 2016, "A Narrative Explanation of Breakpoints and Convergence Patterns in Yugoslavia and its Successor States 1952-2015", The wiiw Balkan Observatory Working Papers, No. 122, June, Vienna: The Vienna Institute for International Economic Studies (wiiw), http://www.balkan-observatory.net/index.php/publications/workingpapers/278-122-a-narrative-explanation-of-breakpoints-and-convergencepatterns-in-yugoslavia-and-its-successor-states-1952-2015 (accessed October 24, 2016).

Blanke, Thomas and Jurgen Hoffmann, 2008, "Towards a European Social Model Preconditions, Difficulties and Prospects of a European Social Policy”, International Journal of Public Policy, 3(1/2), pp. 20-38. https://doi.org/10.1504/ IJPP.2008.017124

Boeri, Tito, 2002, "Social Policy: One for All?", paper presented at the conference "Policy Competition and the Welfare State" organized by CEPII, The Hague, November 29-30. 
Bohle, Dorothee and Béla Greskovits, 2007, "Neoliberalism, Embedded Neoliberalism, and Neocorporatism: Towards Transnational Capitalism in Central-Eastern Europe”, West European Politics, 25(3), pp. 443-466. https:// doi.org/10.1080/01402380701276287

Bohle, Dorothee and Béla Greskovits, 2012, Capitalist Diversity on Europe's Periphery, Ithaca, NY: Cornell University Press.

Buchen, Clemens, 2007, "Estonia and Slovenia as Antipodes" in David Lane and Martin Myant, eds., Varieties of Capitalism in Post-communist Countries, pp. 6589, Basingstoke: Palgrave Macmillan. https://doi.org/10.1057/9780230627574_4

Cernat, Lucian, 2006, Europeanization, Varieties of Capitalism and Economic Performance in Central and Eastern Europe, Basingstoke: Palgrave Macmillan. https://doi.org/10.1057/9780230501683

Csaba, László, 2009, Crisis in Economics?, Budapest: Akadémiai Kiadó.

Ebbinghaus, Bernhard, 1999, "Does a European Social Model Exist and Can it Survive?" in Gerhard Huemer, Michael Mesch and Franz Traxler, eds., The Role of Employer Associations and Labour Unions in the EMU. Institutional Requirements for European Economic Policies, pp. 1-26, Aldershot: Ashgate.

EBRD, 2015, Rebalancing Finance. Transition Report 2015-16, London: European Bank for Reconstruction and Development (EBRD).

EBRD, 2016, Forecasts, Macro Data, Transition Indicators, http:/www.ebrd.com/ what-we-do/economic-research-and-data/data/forecasts-macro-data-transitionindicators.html (accessed March 9, 2016).

Élteto", Andrea, Anikó Magasházi and Andrea Szalavetz, 2015, "Global Value Chains and Upgrading”, Competitio, 14(1), pp. 5-22. https://doi.org/10.21845/ comp/2015/1/1

Estrin, Saul and Milica Uvalic, 2013, "Foreign Direct Investment into Transition Economies: Are the Balkans Different?”, LSE 'Europe in Question' Discussion Paper Series, No. 64, July, London: London School of Economics. 
European Commission, 2008, "Adjustment Capacity of Labour Markets of the Western Balkan Countries”, Economic Papers, No. 346, November, Brussels: European Commission.

European Commission, 2009, Social Protection and Social Inclusion in the Western Balkans, Brussels: European Commission.

European Commission, 2015a, Albania 2015 Report, SWD(2015) 213 final, Brussels: European Commission.

European Commission, 2015b, Bosnia and Herzegovina 2015 Report, SWD(2015) 214 final, Brussels: European Commission.

European Commission, 2015c, Innovation Union Scoreboard 2015, Brussels: European Commission.

European Commission, 2015d, Kosovo 2015 Report, SWD(2015) 215 final, Brussels: European Commission.

European Commission, 2015e, Montenegro 2015 Report, SWD(2015) 210 final, Brussels: European Commission.

European Commission, 2015f, Serbia 2015 Report, SWD(2015) 211 final, Brussels: European Commission.

European Commission, 2015g, The Former Yugoslav Republic of Macedonia 2015 Report, SWD(2015) 212 final, Brussels: European Commission.

Eurostat, 2016, Online Databases, http://ec.europa.eu/eurostat/data/database (accessed January 30, 2016).

Farkas, Beáta, 2011, “The Central and Eastern European Model of Capitalism”, Post-Communist Economies, 23(1), pp. 15-34. https://doi.org/10.1080/14631377 .2011 .546972

Farkas, Beáta, 2016, Models of Capitalism in the European Union - Post-crisis Perspectives, Basingstoke: Palgrave Macmillan. https://doi.org/10.1057/978-1$137-60057-8$ 
Feldmann, Magnus, 2007, “The Origins of Varieties of Capitalism: Lessons from Post-socialist Transition in Estonia and Slovenia” in Bob Hancké, Martin Rhodes and Mark Thatcher, eds., Beyond Varieties of Capitalism. Conflicts, Contradictions, and Complementarities in the European Economy, pp. 328-350, Oxford: Oxford University Press.

Gabrisch, Hubert, Doris Hanzl-Weiss, Mario Holzner, Michael Landesmann, Johannes Pöschl and Hermine Vidovic, 2015, Steigerung der Wettbewerbsfähigkeit in der Balkanregion - Möglichkeiten und Grenzen, Vienna: The Vienna Institute for International Economic Studies (wiiw).

Gligorov, Vladimir, Kosovka Ognjenović and Hermine Vidovic, 2011, Assessment of the Labour Market in Serbia, wiiw Research Report, No. 371, May, Vienna: The Vienna Institute for International Economic Studies (wiiw).

Hall, Peter A. and David Soskice, 2001, "Introduction" in Peter A. Hall and David Soskice, eds., Varieties of Capitalism. The Institutional Foundations of Comparative Advantage, pp. 1-68, Oxford: Oxford University Press.

Hunya, Gábor, 2014, wiiw FDI Report 2014, Central, East and Southeast Europe: Hit by Deleveraging, Vienna: The Vienna Institute for International Economic Studies (wiiw).

IMF, 2015, Government Finance Statistics (GFS), http://data.imf. org/?sk=3C005430-5FDC-4A07-9474-64D64F1FB3DC (accessed April 1, 2016).

Kaufmann, Daniel and Aart Kraay, 2015, Worldwide Governance Indicators, The World Bank, http://info.worldbank.org/governance/wgi/index.aspx\#home (accessed February 8, 2016).

King, Lawrence P., 2007, "Central European Capitalism in Comparative Perspective" in Bob Hancké, Martin Rhodes and Mark Thatcher, eds., Beyond Varieties of Capitalism. Conflicts, Contradictions, and Complementarities in the European Economy, pp. 307-327, Oxford: Oxford University Press. 
Knell, Mark and Martin Srholec, 2007, "Diverging Pathways in Central and Eastern Europe" in David Lane and Martin Myant, eds., Varieties of Capitalism in Post-communist Countries, pp. 40-62, Basingstoke: Palgrave Macmillan. https://doi.org/10.1057/9780230627574_3

Kogan, Irena, Michael Gebel and Clemens Noelke, 2008, Europe Enlarged: A Handbook of Education, Labour and Welfare Regimes in Central and Eastern Europe, Bristol: Policy Press.

Kohl, Heribert, 2010, Social Dialogue, Workers' Rights and Freedom of Association in the Western Balkans, Tirana, Albania: Friedrich Ebert Stiftung, library.fes.de/ pdf-files/bueros/albanien/08106-engl.pdf (accessed March 21, 2016).

Kovtun, Dmitriy, Alexis Meyer Cirkel, Zuzana Murgasova, Dustin Smith and Suchanan Tambunlertchai, 2014, "Boosting Job Growth in the Western Balkans", IMF Working Paper, No. 14/16, January, Washington, DC: International Monetary Fund.

Lane, David, 2007, "Post-state Socialism: A Diversity of Capitalism?" in David Lane and Martin Myant, eds., Varieties of Capitalism in Postcommunist Countries, pp. 13-39, Basingstoke: Palgrave Macmillan. https://doi. org/10.1057/9780230627574_2

Murgasova, Zuzana, Nadeem Ilahi, Jacques Miniane, Alasdair Scott, Ivanna Vladkova-Hollar and IMF staff team, 2015, The Western Balkans: 15 Years of Economic Transition, Washington, DC: International Monetary Fund.

Mykhnenko, Vlad, 2007, "Strengths and Weaknesses of 'Weak' Coordination: Economic Institutions, Revealed Comparative Advantages, and Socio-economic Performance of Mixed Market Economies in Poland and Ukraine" in Bob Hancké, Martin Rhodes and Mark Thatcher, eds., Beyond Varieties of Capitalism. Conflicts, Contradictions, and Complementarities in the European Economy, pp. 351-378, Oxford: Oxford University Press. 
Nölke, Andreas and Arjan Vliegenthart, 2009, "Enlarging the Varieties of Capitalism. The Emergence of Dependent Market Economies in East Central Europe", World Politics, 61(4), pp. 670-702. https://doi.org/10.1017/ S0043887109990098

OECD, 2014, PISA 2012 Results in Focus, Paris: OECD, http://www.oecd.org/ pisa/keyfindings/pisa-2012-results-overview.pdf (accessed May 23, 2014).

Sanfey, Peter, Jakov Milatović and Ana Krešić, 2016, "How the Western Balkans can Catch Up”, EBRD Working Paper, No. 185, London: European Bank for Reconstruction and Development (EBRD).

Sapir, André, 2006, "Globalization and the Reform of European Social Models", Journal of Common Market Studies, 44(2), pp. 369-390. https://doi.org/10.1111/ j.1468-5965.2006.00627.x

Schneider, Friedrich, A.T. Kearney and Visa, 2013, The Shadow Economy in Europe, 2013, Korea: A.T. Kearney, Inc., https://www.atkearney.com/ documents/10192/1743816/The+Shadow+Economy+in+Europe+2013.pdf (accessed July 13, 2014).

Schwab, Klaus and Xavier Sala-i-Martin, 2015, The Global Competitiveness Report 2015-2016, Geneva: World Economic Forum.

Schweickert, Rainer, Markus Ahlborn, Karol Frank, Ágnes Orosz, Ivana Sikulová and Miklós Szanyi, 2013, "Large-scale Transformation of Socio-economic Institutions - Comparative Case Studies on CEECs", WWWforEurope Interim Report Working Paper, No. 16, July, Vienna and Brussels: WIFO Austrian Institute of Economic Research and European Commission, http:// www.wifo.ac.at/jart/prj3/wifo/resources/person_dokument/person_dokument. jart?publikationsid $=46871 \&$ mime_type $=$ application/pdf (accessed August 8, 2013). 
Szanyi, Miklós, 2013, "Large-scale Transformation of Socio-economic Institutions - Comparative Case Studies on CEECs. Background Paper 3: Varieties of Capitalism and CEECs", WWWforEurope Working Paper, No. 19, July, Vienna and Brussels: WIFO - Austrian Institute of Economic Research and European Commission, http:/www.foreurope.eu/fileadmin/documents/pdf/ Workingpapers/WWWforEurope_WPS_no019_MS23_Backgroundpaper3. pdf (accessed August 8, 2013).

The Vienna Institute for International Economic Studies (wiiw), 2016, "Falling Behind and Catching Up - Southeast Europe", website article, News \& Events, http://wiiw.ac.at/falling-behind-and-catching-up--southeast-europe-n-166.html (accessed October 24, 2016).

The World Bank, 2010, The Crisis Hits Home: Stress-testing Households in Europe and Central Asia, Washington, DC: World Bank.

The World Bank, 2015, Personal Remittances, Received (\% of GDP), http://data. worldbank.org/indicator/BX.TRF.PWKR.DT.GD.ZS (accessed March 29, 2016).

The World Bank, 2015, Gross Enrolment Ratio, Tertiary, Both Sexes (\%), http:// data.worldbank.org/indicator/SE.TER.ENRR (accessed March 24, 2016).

The World Bank, 2016a, Doing Business 2016: Measuring Regulatory Quality and Efficiency, Washington, DC: World Bank.

The World Bank, 2016b, The Global Financial Development Database, http:// data.worldbank.org/data-catalog/global-financial-development (accessed March 9, 2016).

UNECE, 2004, Economic Survey of Europe, No. 2. Statistical Appendix, Geneva, UNECE, http://www.unece.org/fileadmin/DAM/ead/pub/042/042appendix. pdf (accessed February 3, 2016).

UNU-WIDER, 2015, World Income Inequality Database (WIID3c), https:// www.wider.unu.edu/project/wiid-world-income-inequality-database (accessed February 3, 2016). 